\title{
A New Abdominally Parasitizing Bopyrid, Anisarthrus okunoi sp. nov. (Crustacea: Isopoda), Infesting the Hinge-Beak Shrimp Rhynchocinetes uritai Kubo, 1942 (Crustacea: Decapoda: Rhynchocinetidae)
}

\author{
Nobuhiro Saito ${ }^{1,3}$ and Michitaka Shimomura ${ }^{2}$ \\ ${ }^{1}$ Suido-sha Co. Ltd., Ikuta 8-11-11, Tama-ku, Kawasaki, Kanagawa 214-0038, Japan \\ E-mail:nsaitoh@suidosha.co.jp \\ ${ }^{2}$ Kitakyushu Museum of Natural History and Human History, \\ Higashida 2-4-1, Yahatahigashi-ku, Kitakyushu, Fukuoka 805-0071, Japan \\ E-mail: shimomura@kmnh.jp \\ ${ }^{3}$ Corresponding author
}

(Received 8 October 2014; Accepted 22 January 2015)

\begin{abstract}
Anisarthrus okunoi sp. nov., an abdominal parasite of the hinge-beak shrimp Rhynchocinetes uritai Kubo, 1942, is described from Awaji Island, central Japan. The new bopyrid, the second species of Anisarthrus, is distinguished from A. pelseneeri Giard, 1907 from Boulogne, France, by the lateral plates of the concave side being smaller than those of the convex side, the large, lanceolate pleopods 1-2 and slightly bilobed pleopods 3-4, the simple, bulbous pleotelson in the female, the lack of eyes, and the rounded posterior margin of the pleotelson in the male. This is the first record of bopyrid infestation of any member of the family Rhynchocinetidae in the world.
\end{abstract}

Key Words: Crustacea, Isopoda, Bopyridae, Anisarthrus okunoi sp. nov., Rhynchocinetes uritai, Awaji Island, Japan.

\section{Introduction}

In Japan, 96 species of bopyrid isopod have been recorded (Shiino 1972; Saito et al. 2000, 2010; Shimomura et al. 2006, 2012; Miura et al. 2014). They infest species in various infraorders of decapod crustaceans inhabiting marine, brackish-, or fresh-water habitats. Eleven species of Japanese bopyrids, including two unidentified species, occur on the ventral surfaces of the abdomens of 14 species of caridean shrimp in four families (Saito et al. 2000; Shimomura et al. 2006; Saito and Motoh 2010) (see Discussion). The hingebeak shrimp Rhynchocinetes uritai Kubo, 1942 (Rhynchocinetidae) is known from southern Japanese and Korean waters and is common subtidally in central Japan (Hayashi 2007), but it has not previously been known to host any bopyrid parasite, either branchially or abdominally (Saito 2002). Junji Okuno, Coastal Branch of Natural History Museum and Institute, Chiba, found an unidentified bopyrid isopod on the ventral surface of the pleon of a specimen of $R$. uritai during a recent survey on the south coast of Awaji Island, central Japan, and kindly made it available for our examination. It proved to represent a new species of Anisarthrus Giard, 1907, which we describe herein.

\section{Materials and Methods}

A specimen of the hinge-beak shrimp Rhynchocinetes uritai, host of the new bopyrid isopod, was caught by a trap in Yura Harbor on the southeastern coast of Awaji Island, central Japan, in 2008. The specimen was preserved in $70 \%$ ethanol and examined under a binocular microscope (LEICA MZ 12). Measurements and drawings were made with the aid of an Olympus BHB-Tr microscope equipped with a drawing tube.

Measurements provided are body length (BL: measured from tip of head to posterior end of final pleomere along dorsal mid-line) of the bopyrid and postorbital carapace length (CL: measured from posterior margin of orbit to midpoint of posterodorsal margin of carapace) of the host shrimp. Other measurements and terminology essentially follow those of Markham (1985) for the bopyrid and Hayashi (2007) for the host shrimp. The type specimens of the new bopyrid isopod are deposited in the Kitakyushu $\mathrm{Mu}-$ seum of Natural History and Human History (KMNH IvR), Kitakyushu, Japan, and their host shrimp is deposited in the Coastal Branch of Natural History Museum and Institute, Chiba (CMNH), Katsuura, Chiba, Japan.

Family Bopyridae Rafinesque, 1815

Subfamily Hemiarthrinae Markham, 1972

Genus Anisarthrus Giard, 1907

Anisarthrus okunoi sp. nov.

[Japanese name: Sarasa-no-harayadori]

(Figs 1-3)

Material examined. Holotype: ovigerous female (BL 

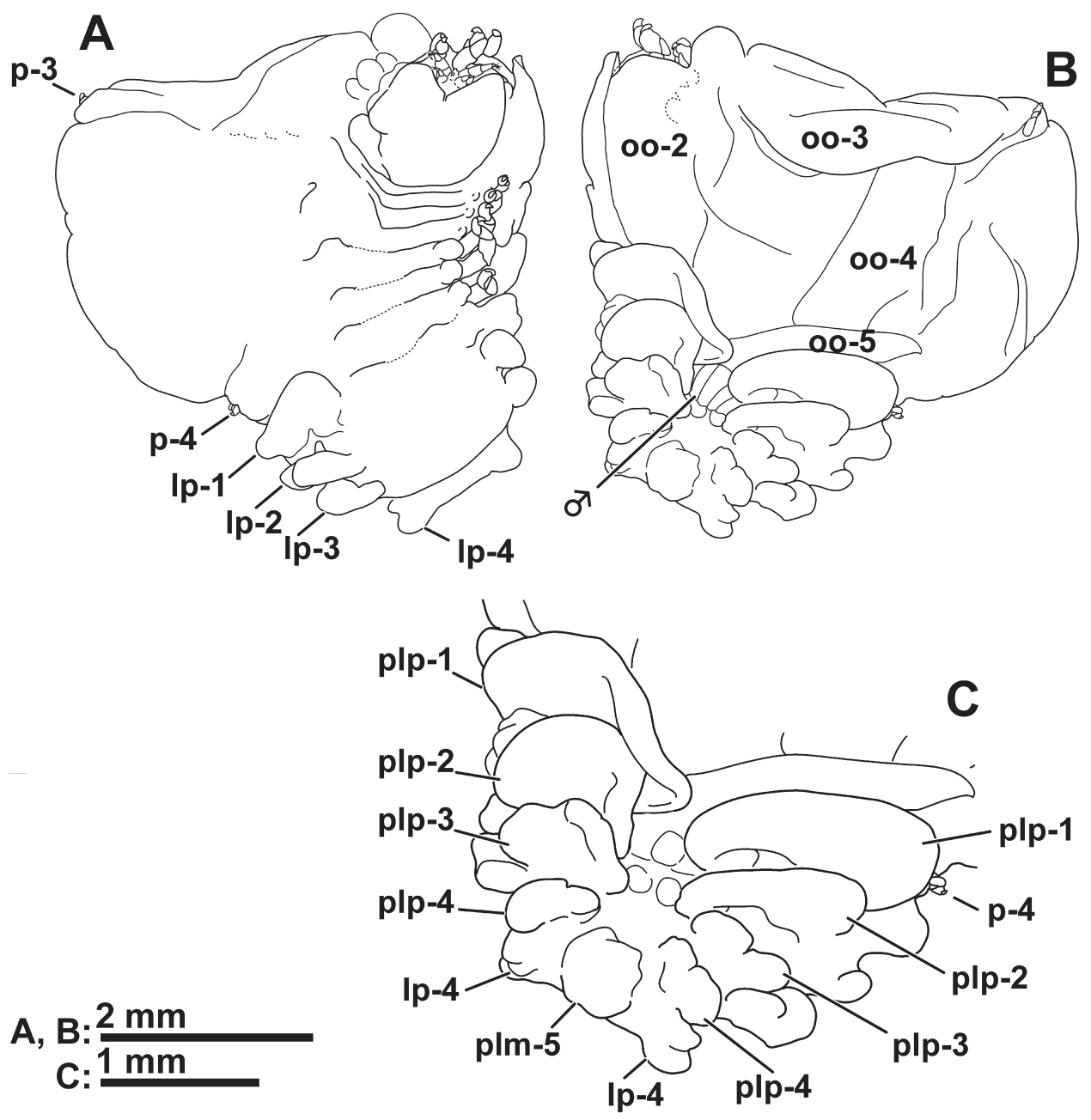

Fig. 1. Anisarthrus okunoi sp. nov., holotype female, $3.88 \mathrm{~mm} \mathrm{BL}$, KMNH IvR 500,727, Yura Harbor, Sumoto, Awaji Island, central Japan, $6 \mathrm{~m}$ depth, originally attached to ventral surface of pleon of hinge-beak shrimp Rhynchocinetes uritai Kubo, 1942. A, dorsal view; B, ventral view, with partly hidden male ( $\hat{0}$; $1.12 \mathrm{~mm} \mathrm{BL}, \mathrm{KMNH}$ IvR 500,728); C, pleon, ventral. Abbreviations: lp-1-4, lateral plates 1-4; oo-2-5, oostegites 2-5; p-3-4, pereopods 3-4; plm-5, pleomere 5 (=pleotelson); plp-1-4, pleopods 1-4.

$3.88 \mathrm{~mm}$ ), KMNH IvR 500,727, removed from ventral surface of pleon of hinge-beak shrimp Rhynchocinetes uritai (female, CL $6.98 \mathrm{~mm}$ ), CMNH-ZC 02342, Yura Harbor $\left(34^{\circ} 17^{\prime} 30^{\prime \prime} \mathrm{N}, 134^{\circ} 57^{\prime} 00^{\prime \prime} \mathrm{E}\right)$, Sumoto city, Awaji Island, Hyogo Prefecture, central Japan, $6 \mathrm{~m}$ depth, 22 October 2008, coll. J. Okuno, K. Hanano, and T. Tamego. Allotype: male (BL $1.12 \mathrm{~mm}$ ), KMNH IvR 500,728, removed from pleon of holotype female.

Description of holotype female (KMNH IvR 500,727). Body (Fig. 1A, B) markedly asymmetrical, greatly expanded on convex (left) side, approximating an inverted equilateral triangle in general outline; body axis distortion about $40^{\circ}$; maximal body width about 1.2 times as long as body length.

Head (Fig. 1A) quadrilateral, completely embedded in pereon, representing about $35 \%$ of body length; frontal margin concave and deeply cleft. Eyes absent. Right antenna 1 (Fig. $2 \mathrm{~A}$ ) of 3 articles, articles 2 and 3 with distal and terminal setae, respectively; right antenna 2 (Fig. 2B) of 5 articles, of which articles 2, 3, and 4 with marginal and distal setae, article 5 with terminal setae. Right and left maxillipeds (Fig. 2C, D) symmetrical, semi-ovoidal, nearly straight medially, roundly angled anteriorly, without palp, bearing short spur; anterior article about 2.4 times as long as posterior article. Barbula (Fig. 2E) with pair of short, stout lateral projections, its lateral margins expanded and mid-region produced slightly into medial point.

Pereon (Fig. 1A): pereomeres 1 and 2 completely distinct dorsally; pereomeres 3-7 distinct on concave (right) side and medially but segmental boundaries not clearly expressed on convex (left) side. All pereomeres with dorsolateral bosses on concave side. Inflated closed brood pouch (Fig. 1B) expanded far laterally, formed of fused convex oostegites 2-5. Oostegite 1 of convex side (Fig. 2F) bilobed; that of concave side (Fig. 2G) oval, not segmented, lacking posterolateral point. Oostegites $2-5$ of concave side all separated and aligned. Seven pereopods on each side of body; on both sides, first two pairs of pereopods adjacent to head: both pairs large and with all articles distinct, basis rectangular, ischium trapezoidal and shorter than basis, merus trapezoidal with short spines on inferior margin, carpus triangular, propodus ovate, dactylus stout (Fig. $2 \mathrm{H}$ ). Pereopods 3 and 4 of convex side widely separated by expanded part of pereomere (Fig. 1A). Pereopods 5-7 present on posterior margin of pleon, covered by left pleopod 1 (Fig. 2I). 

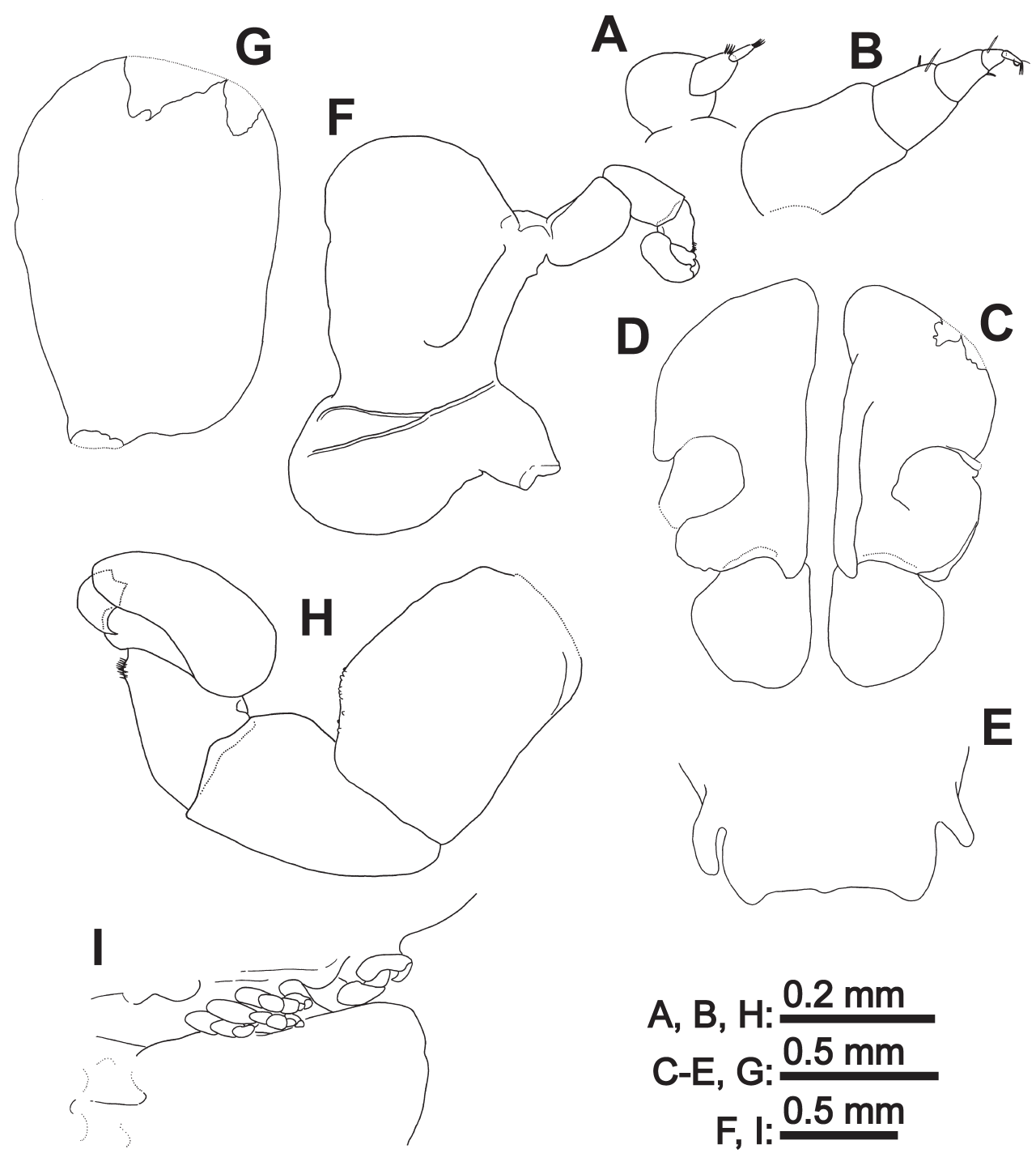

Fig. 2. Anisarthrus okunoi sp. nov., holotype female, $3.88 \mathrm{~mm}$ BL, KMNH IvR 500,727. A, right antenna 1, dorsal view; B, right antenna 2, dorsal view; C, left maxilliped, ventral view; D, right maxilliped, ventral view; E, barbula, ventral view; F, left oostegite 1, ventral view; G, right oostegite 1, ventral view; $\mathrm{H}$, left pereopod 1 , lateral view; I, left pereopods 4-7, with pleopod 1 removed, ventral view.

Pereopods 3-7 of concave side tightly clumped (Fig. 1A).

Pleon (Fig. 1A-C): all pleomeres fused dorsally; pleomeres 1-4 distinct laterally and ventrally; pleomere 1 bearing single midventral tubercle, pleomere 2 with two similar ventral tubercles; pleomere 5 (= pleotelson) in form of simple bulb visible only in ventral view. Four pairs of large lamellar lateral plates and four pairs of pleopods present, all well-developed; lateral plates (Fig. 1A) irregularly oval, shorter posteriorly; those on concave side smaller than those opposite. Pleopods (Fig. 1C) uniramous, first two large, lanceolate; pleopods 3 and 4 slightly bilobed and smaller than pleopods 1 and 2. Uropods absent.

Description of allotype male (KMNH IvR 500,728). Body (Fig. 3A-C) small, about $29 \%$ as long as female, elliptical in general outline; body width $54 \%$ of body length, with maximal width at pereomere 5 .

Head (Fig. 3A) distinct from pereomere 1, semicircular, with tiny medial notch on anterior margin, slightly longer than pereomere 1. Eyes absent. Antenna 1 (Fig. 3D) short, of 3 articles; articles 2 and 3 each with tuft of long seta dis- tally. Antenna 2 (Fig. 3D) of 7 articles, surpassing midpoint of pereomere 1 .

All pereomeres (Fig. 3A-C) distinctly demarcated dorsally, lacking tubercles ventrally; lateral margins convex; pereomere 7 and pleon distinct laterally on both sides, fused in central region both dorsally and ventrally. Pereopods (Fig. 3E) all of similar size and structure; all articles similar to those of female in segmentation.

Pleon (Fig. 3A, C) completely fused, semi-ovoidal, representing $27 \%$ of whole body length; posterior margin rounded, smooth, without anal tube or long taper. Pleopods and uropods absent.

Etymology. Named in honour of the collector, Dr. Junji Okuno, in recognition of his contribution to the knowledge of the hinge-beak shrimps.

\section{Discussion}

Comparison. Several features of the female indicate 

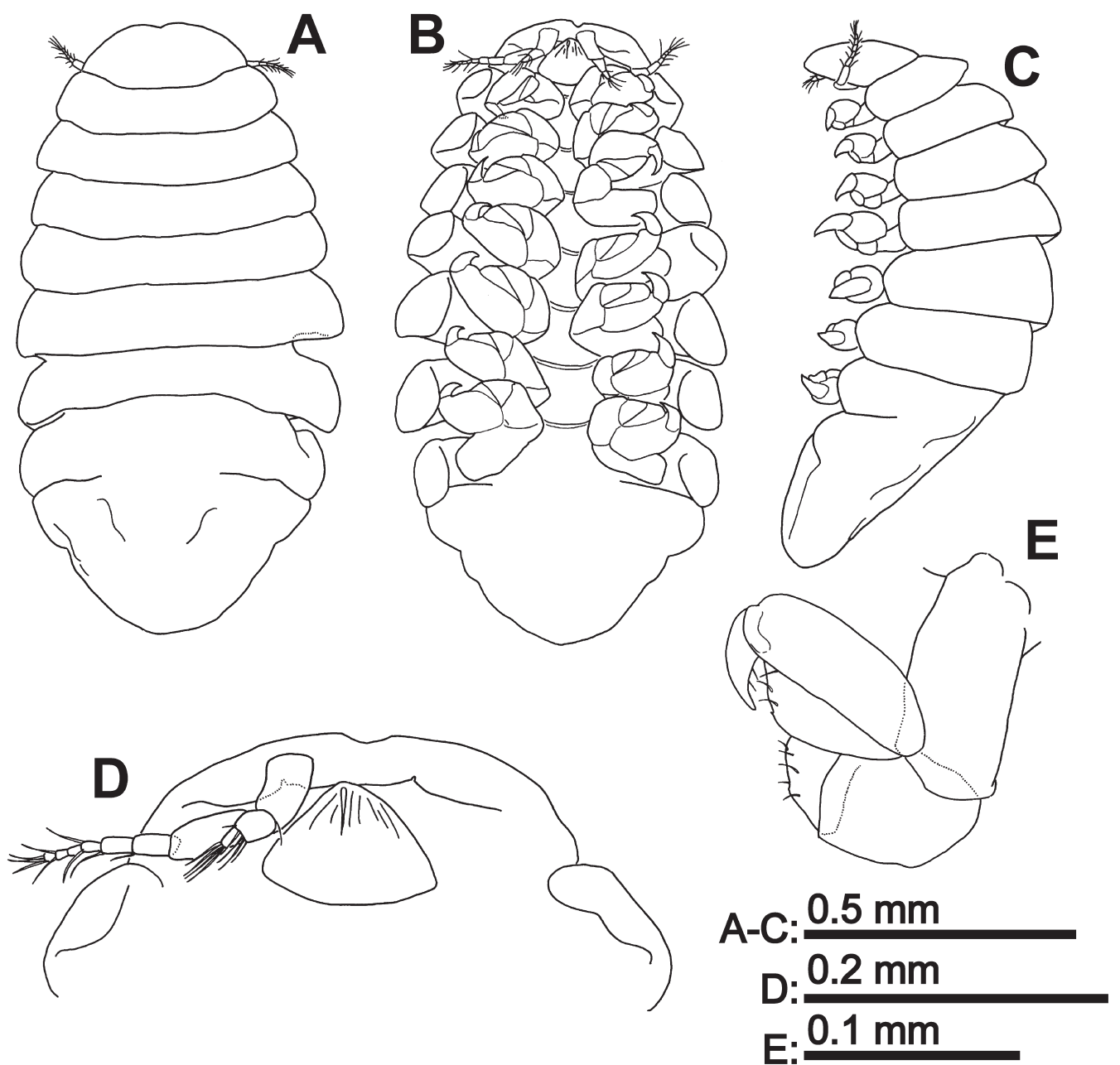

Fig. 3. Anisarthrus okunoi sp. nov., allotype male, $1.12 \mathrm{~mm} \mathrm{BL}$, KMNH IvR 500,728, originally attached to ventral surface of pleon of holotype female. A, dorsal view; B, ventral view; C, left lateral view; D, anteroventral view of head with right antennae 1 and 2; E, left pereopod 1, lateral view.

that the new bopyrid species belongs to the genus Anisarthrus [cf. diagnosis provided by Codreanu and Codreanu (1956a) and Markham (1972)]: pereomeres 1 and 2 are completely distinct dorsally; pereomeres 3-7 are distinct on the concave side and medially but not clearly so on the convex side; the pleomeres are fused dorsally; pleomere 5 (=pleotelson) is present; there are seven pereopods on both sides of the pereon; the first two pairs of pereopods are adjacent to head; there are four pairs of large lamellar lateral plates and four pairs of pleopods, all lacking endopodites; and there are no uropods. In the male, pereomere 7 and the pleon are distinct laterally but fused centrally, and all the pleomeres and pleotelson are completely fused.

The presence in female of Anisarthrus of all seven pereopods on both sides of the body links this genus to five other genera of the subfamily Hemiarthrinae: Eophrixus Caroli, 1930, Apophrixus Nierstrasz and Brender à Brandis, 1931, Hypophryxus Shiino, 1934, Loki Markham, 1972, and Cataphryxus Shiino, 1936. Anisarthrus can be separated from the first four genera by the absence of uropods in the female. In this respect, it appears most closely related to Cataphryxus, but it can be readily distinguished from the latter by the following features [cf. diagnosis of Cataphryxus provided by Shiino (1936)]: in the female of Anisarthrus, the lateral plates of pleon are irregularly oval, and the pleopodal endopodites are absent, while in the female of Cataphryxus, the lateral plates are well-developed, deeply biramous, and lanceolate, and the pleopodal endopodites are present; in male of Anisarthrus, the last pereomere and pleon are fused centrally, whereas in male of Cataphryxus they are clearly distinct.

Until now, Anisarthrus has contained only the type species A. pelseneeri Giard, 1907 from Boulogne, France, an abdominal parasite of the alpheid shrimp Athanas nitescens (Leach, 1813) (Giard 1907). Anisarthrus pelseneeri was redescribed in detail by Codreanu and Codreanu (1956a, 1956b). Anisarthrus okunoi sp. nov. can be readily distinguished from A. pelseneeri by the following morphological features of the female (those of $A$. pelseneeri in parentheses): the lateral plates of the concave side are smaller than those of the convex side (these of both sides subequal), the pleopods 1-2 are large and lanceolate and pleopods 3-4 are semi-biramous (elliptical and uniramous, respectively), and the pleotelson is a simple bulb (reduced). Furthermore, two features of the male also serve to separate these species: eyes are absent in A. okunoi (present and fairly large in A. pelse- 

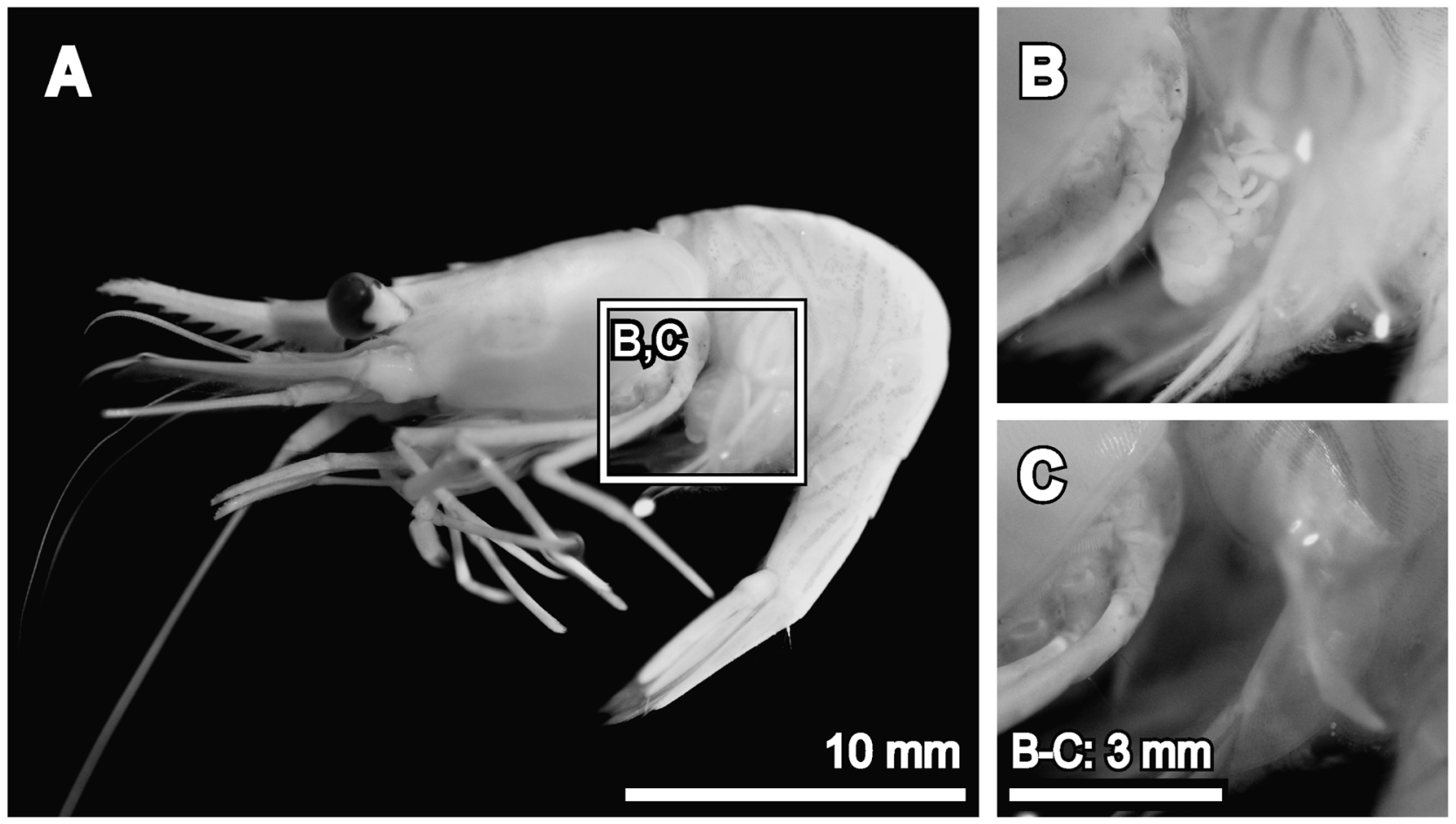

Fig. 4. Rhynchocinetes uritai Kubo, 1942, female, $6.98 \mathrm{~mm} \mathrm{CL}$, CMNH-ZC 02342, host shrimp of Anisarthrus okunoi sp. nov., Yura Harbor, Sumoto, Awaji Island, central Japan, $6 \mathrm{~m}$ depth. A, left lateral view; B, region of attachment, anteroventral surface of pleon, between pereopod 5 and pleopod 1; C, same region after removal of female parasite, showing clear gape.

Table 1. List of bopyrid species that occur on the abdomens of Japanese caridean shrimps.

\begin{tabular}{|c|c|c|c|c|}
\hline Species & Host (Family) & Infesting position & Locality & Reference \\
\hline $\begin{array}{l}\text { Anisarthrus okunoi sp. } \\
\text { nov. }\end{array}$ & $\begin{array}{l}\text { Rhynchocinetes uritai Kubo, } 1942 \\
\text { (Rhynchocinetidae) }\end{array}$ & $\begin{array}{l}\text { antero-ventral sur- } \\
\text { face of pleonite } 1\end{array}$ & Awaji I., Hyogo & present study \\
\hline Anisarthrus sp. & $\begin{array}{l}\text { Arete dorsalis Stimpson, } 1860 \\
\quad \text { (Alpheidae) }\end{array}$ & ventral surface & Shirahama, Wakayama & Nakashima (1995) \\
\hline $\begin{array}{l}\text { Anomophryxus deforma- } \\
\text { tus Shiino, } 1937\end{array}$ & $\begin{array}{l}\text { Plesionika ortmanni Doflein, } 1902 \\
\quad \text { (Pandalidae) }\end{array}$ & $\begin{array}{l}\text { ventral surface of } \\
\text { pleonite } 5\end{array}$ & Tanabe, Wakayama & Shiino (1937) \\
\hline $\begin{array}{l}\text { Cataphryxus primus } \\
\text { (Shiino, 1934) }\end{array}$ & Lysmata sp. (Hippolytidae) & ventral surface & Shirahama, Wakayama & Shiino (1934) \\
\hline $\begin{array}{l}\text { Diplophryxus alphei } \\
\text { Shiino, } 1934\end{array}$ & Alpheus spp. (Alpheidae) & ventral surface & Shirahama, Wakayama & Shiino (1934) \\
\hline $\begin{array}{l}\text { Diplophryxus jordani } \\
\text { Richardson, } 1904\end{array}$ & $\begin{array}{l}\text { Palaemon pacificus (Stimpson, } \\
\text { 1860); P. serrifer (Stimpson, } \\
\text { 1860) (Palaemonidae) }\end{array}$ & ventral surface & $\begin{array}{l}\text { Misaki, Kanagawa; } \\
\text { Wakura, Ishikawa; } \\
\text { Shirahama, Wakayama }\end{array}$ & Shiino (1933) \\
\hline $\begin{array}{l}\text { Eophrixus kuboi (Shiino, } \\
\text { 1939) }\end{array}$ & $\begin{array}{l}\text { Cuapetes akiensis (Kubo, 1936) } \\
\text { (Palaemonidae) }\end{array}$ & ventral surface & $\begin{array}{l}\text { Shimokamogari, Hiro- } \\
\text { shima }\end{array}$ & Shiino (1939) \\
\hline $\begin{array}{l}\text { Eophrixus shojii Shiino, } \\
\quad 1941\end{array}$ & $\begin{array}{l}\text { Alpheus digitalis De Haan, 1844; A. } \\
\text { japonicus Miers, } 1879 \text { (Alphei- } \\
\text { dae) }\end{array}$ & ventral surface & $\begin{array}{l}\text { Momotori, Mie; Tomio- } \\
\text { ka, Amakusa }\end{array}$ & Shiino $(1941,1958)$ \\
\hline $\begin{array}{l}\text { Hemiarthrus abdominalis } \\
\quad \text { (Krøyer, 1840) }\end{array}$ & $\begin{array}{l}\text { Eualus biunguis (Rathbun, 1902); } \\
\text { Lebbeus longipes (Kobjakova, } \\
\text { 1936); L. kuboi Hayashi, 1992; } \\
\text { Spirontocaris spp. (Hippolytidae) }\end{array}$ & $\begin{array}{l}\text { antero-ventral sur- } \\
\text { face of pleonite } 1\end{array}$ & $\begin{array}{l}\text { off Hokkaido; Sea of Ok- } \\
\text { hotsk; Yamato Bank; } \\
\text { Toyama Bay; Sea of } \\
\text { Japan }\end{array}$ & $\begin{array}{l}\text { Saito et al. (2001); } \\
\text { Saito and Motoh } \\
\text { (2010) }\end{array}$ \\
\hline Hemiarthrus sp. & $\begin{array}{l}\text { Arete dorsalis Stimpson, } 1860 \\
\quad \text { (Alpheidae) }\end{array}$ & ventral surface & Shirahama, Wakayama & Nakashima (1995) \\
\hline $\begin{array}{l}\text { Hypophryxus yusakiensis } \\
\text { Shiino, } 1934\end{array}$ & Alpheus spp. (Alpheidae) & ventral surface & Shirahama, Wakayama & Shiino (1934) \\
\hline $\begin{array}{l}\text { Metaphrixus setouchiensis } \\
\text { Shimomura, Ohtsuka } \\
\text { and Sakakihara, } 2006\end{array}$ & Hippolyte sp. (Hippolytidae) & ventral surface & Takehara, Hiroshima & $\begin{array}{l}\text { Shimomura et al. } \\
\text { (2006) }\end{array}$ \\
\hline
\end{tabular}


neeri) and the posterior margin of the pleotelson is rounded in A. okunoi (produced into an anal tube in A. pelseneeri). Nakashima (1995) reported an unidentified bopyrid as a species of Anisarthrus from Shirahama, Japan, but he did not describe it, so its placement in the genus is uncertain.

Host- and site-specificity. Anisarthrus okunoi sp. nov. infests the common hinge-beak shrimp Rhynchocinetes uritai (Fig. 4A). The present female attached to the anteroventral surface of the host's pleon, between pereopod 5 and pleopod 1 (Fig. 4B); after the female bopyrid was removed from the host, a conspicuous gape remained at the point of attachment (Fig. 4C). The female bopyrid faced upward with its ventral side oriented anteriorly on the host shrimp (Fig. 4B). It was attached by pereopods 1 and 2 to the ventral surface of the first abdominal segment of the host; pereopods 3-7 of the female's concave side hooked to the peduncle of pleopod 1 of the host. One male bopyrid attached to the ventral side of the female's pleon (Fig. 1B), facing laterally.

Up until now, 11 species of bopyrid isopod, two of them unidentified, have been reported as abdominal parasites of Japanese caridean shrimps (Saito et al. 2000; Shimomura et al. 2006) (Table 1). They have been reported from 14 species of caridean shrimps in four families. Richardson (1904) also reported an unidentified hemiarthrinid species, designated as Phryxus sp., from an unknown host at Omai Zaki (i.e., Cape Omai), Japan. Most of these bopyrids infest one or at most two species of host, but Hemiarthrus abdominalis (Krøyer, 1840) infests several host species (Saito and Motoh 2010). Anisarthrus okunoi is not only the first known bopyrid parasite of Rhynchocinetes uritai, but also the first one reported to infest any member of the family Rhynchocinetidae in the world. Anisarthrus okunoi and Hemiarthrus abdominalis were found attached to the antero-ventral surface of pleonite 1 (Saito et al. 2001; present study) whereas Anomophryxus deformatus was found on the surface of pleonite 5 (Shiino 1937). The precise situation on the host's ventral surface of the other nine species listed in Table 1 has not been described in detail (Shiino 1933, 1934, 1939, 1941; Nakashima 1995; Shimomura et al. 2006).

\section{Acknowledgments}

We are grateful to Junji Okuno (Coastal Branch of Natural History Museum and Institute, Chiba) as well as Koichi Hanano and Tomoyasu Tamego (Organization for Preserving Environments of Narugashima, Hyogo), for providing the material used in this study. John Markham (Arch Cape Marine Laboratory, Arch Cape, Oregon) made helpful suggestions concerning early drafts of this paper. Jason D. Williams (Hofstra University, Hempstead, New York) and an anonymous reviewer are thanked for their useful comments on this manuscript.

\section{References}

Codreanu, M. and Codreanu, R. 1956a. Un epicarid abdominal nou pentru Marea Neagra, Anisarthrus pelseneeri Giard 1907, parazit pe creveta Athanas nitescens Leach. Revisuirea si raspindirea genului Anisarthrus. Buletin Stiintific. Academia Republicii Populare Romîne. Sectia de Biologie si Stiinte Agricole 8: 568-584.

Codreanu, M. and Codreanu, R. 1956b. Sur l'Anisarthrus pelseneeri, épicaride parasite abdominal de la crevette Athanas nitescens; sa présence dans la Mer Noire et la dispersion du genre Anisarthrus. Bulletin Biologique de la France et de la Belgique 90: 111-121.

Giard, A. 1907. Sur l'Anisarthrus pelseneeri (nov. gen. et nov. sp.) bopyrien parasite d'Athanas nitescens Leach et sur la synonymie du genre Hemiarthrus. Comptes Rendus de la Société de Biologie 63: 321-324.

Hayashi, K. 2007. Caridean Shrimps (Crustacea: Decapoda: Pleocyemata) from Japanese Waters Part 1. Seibutsu Kenkyusha, Tokyo, xiv +292 pp. [In Japanese]

Markham, J. C. 1972. Two new genera of western Atlantic abdominally parasitizing Bopyridae (Isopoda, Epicaridea), with a proposed new name for their subfamily. Crustaceana, Supplement 3: 39-56.

Markham, J. C. 1985. A review of the bopyrid isopods infesting caridean shrimps in the northwestern Atlantic Ocean, with special reference to those collected during the Hourglass cruises in the Gulf of Mexico. Memoirs of the Hourglass Cruises 7: 1-156.

Miura, T., Utsunomiya, M., Kitashima, Y., and Tomioka, H. 2014. First record on the bopyrid isopods, parasitic on marine crustaceans collected from Miyazaki Prefecture, Japan (preliminary report). Bulletin of the Faculty of Agriculture, University of Miyazaki 60: 29-39. [In Japanese with English abstract]

Nakashima, Y. 1995. Can small male shrimps achieve copulation in the presence of larger ones? Journal of Ethology 13: 9-16.

Rafinesque-Schmaltz, C. S. 1815. Analyse de la Nature, ou tableau de l'univers et des corps organisés. Palerme: 1-224.

Richardson, H. 1904. Contributions to the natural history of the Isopoda. Proceedings of the United States National Museum 27: $1-89$.

Saito, N. 2002. A list of crustacean hosts of the epicaridean isopods (Crustacea: Peracarida) in the Japanese waters. Taxa (Proceedings of the Japanese Society of Systematic Zoology) 13: 18-31. [In Japanese with English abstract]

Saito, N., Itani, G., and Nunomura, N. 2000. A preliminary check list of isopod crustaceans in Japan. Bulletin of the Toyama Science Museum 23: 11-107. [In Japanese with English abstract]

Saito, N. and Motoh, H. 2010. Note on a bopyrid isopod infected on the abdomen of the hippolytis shrimp, Lebbeus kuboi Hayashi, 1992. Cancer 19: 15-17. [In Japanese]

Saito N., Shokita, S. and Naruse, T. 2010. A new species of freshwater bopyrid, Probopyrus iriomotensis (Crustacea: Isopoda), parasitizing Macrobrachium spp. (Crustacea: Decapoda), from Iriomote Island, Ryukyu Islands, southwestern Japan. Species Diversity 15: 169-183.

Saito, N., Yosho, I. and Hashizume, K. 2001. Bopyrid isopods found from shrimps in the Sea of Japan. Nihonkaiku Suisan Siken Kenkyu Renraku News 394: 6-9. [In Japanese]

Shiino, S. M. 1933. Bopyrids from Tanabe Bay. Memoirs of the College of Science, Kyoto Imperial University, Series B 8: 249-300.

Shiino, S. M. 1934. Bopyrids from Tanabe Bay, II. Memoirs of the College of Science, Kyoto Imperial University, Series B 9: 257-287.

Shiino, S. M. 1936. Bopyrids from Tanabe Bay, III. Memoirs of the College of Science, Kyoto Imperial University, Series B 11: 157174.

Shiino, S. M. 1937. Bopyrids from Tanabe Bay, IV. Memoirs of the College of Science, Kyoto Imperial University, Series B 12: 479493.

Shiino, S. M. 1939. A new phryxid (Epicaridea) from the Inland Sea. Annotationes Zoologicae Japonenses 18: 17-20. 
Shiino, S. M. 1941. Further notes on bopyrids from Kyusyu and Ryukyu. Annotationes Zoologicae Japonenses 20: 154-158.

Shiino, S. M. 1958. Note on the bopyrid fauna of Japan. Report of the Faculty of Fisheries, Prefecture University of Mie 3: 29-73.

Shiino, S. M. 1972. [The Epicaridea (list of species) from Japan]. Kansai Shizenkagaku 24: 7-10. [In Japanese]

Shimomura, M., Ohtsuka, S. and Hashimoto, J. 2012. New distribution and host record of a penaeid ectoparasitic isopod, Minicopenaeon intermedium intermedium Bourdon, 1981 (Crustacea: Bopyridae). Bulletin of the Kitakyushu Museum of Natural History and Human History, Series A (Natural History) 10: 1-8.

Shimomura, M., Ohtsuka, S. and Sakakihara, T. 2006. Two bopyrid isopods infesting caridean shrimp Hippolyte sp. in the Seto Inland Sea, western Japan (Crustacea: Peracarida). Bulletin of the Kitakyushu Museum of Natural History and Human History, Series A (Natural History) 4: 1-7. 